\title{
ACCOUNTING FOR ANOMALOUS HYDRAULIC RESPONSES DURING CONSTANT-RATE PUMPING TESTS IN THE PRAIRIE DU CHIEN-JORDAN AQUIFER SYSTEM - TOWARDS A MORE ACCURATE ASSESSMENT OF LEAKAGE
}

\author{
Justin L. Blum \\ Minnesota Department of Health, 625 North Robert Street, St.Paul, Minnesota, 55156,USA, justin.blum@state.mn.us
}

\begin{abstract}
The Prairie du Chien-Jordan Aquifer system is an important source of drinking water for residents of southeastern Minnesota. Assessment of the hydraulic properties of this aquifer continues to be of interest for wellhead protection and resource evaluation efforts. When performing constant-rate pumping tests on wells constructed in the karsted Prairie du Chien Aquifer, anomalous hydraulic responses resulting from cavernous flow are frequently observed. Hydraulic response in the adjacent Jordan Sandstone Aquifer is also commonly distorted because of bedding-plane fractures and well development techniques such as blasting and bailing. Resolution of these anomalous responses is important for accurate estimates of leakage through adjacent resistive layers. Examples are presented with a rationale for the analysis process.
\end{abstract}

\section{Introduction}

The hydraulic properties of fractured and karsted rocks are notoriously variable. (Teutsch \& Sauter, 1991) Standard aquifer tests characterize only a small volume of rock relative to the size of regional aquifer systems. Nevertheless, a sufficiently large number of tests may begin to describe various hydraulic characteristics and types or patterns of hydraulic response may be distinguished. This dataset informs the analysis to reduce uncertainty in estimated hydraulic properties.

Typically, hydraulic conductivity and storativity are derived from a constant-rate pumping test. In a layered system if observation well data were collected and the test period was sufficiently long, the hydraulic resistance of adjacent aquitards may also be estimated. With other information, the hydraulic resistance is used to calculate the rate of pumping-induced leakage to the aquifer. A realistic estimate of the rate of leakage is an important parameter for construction and calibration of regional groundwater flow models of layered systems.

The Minnesota Department of Health (MDH) has compiled a dataset of approximately seventy-five aquifer tests performed on wells constructed in the Prairie du
Chien-Jordan Aquifer (PDC-J) system (Figure 1). The tests were conducted for a variety of purposes by drilling contractors, environmental consultants, and state and federal agencies since 1960. The majority of tests were performed on high-capacity wells for wellhead protection planning or to satisfy other regulatory permit requirements. Acquisition and analysis of test data continues.

The extent of the aquifer system in Minnesota is greater than 23,300 sq. kilometers (9000 sq. miles) (Figure 1). This represents a test density of about one test per 310 sq. km. (120 sq. mi). In view of the expense of conducting an aquifer test, the scarcity of appropriately constructed wells from which to obtain water levels and

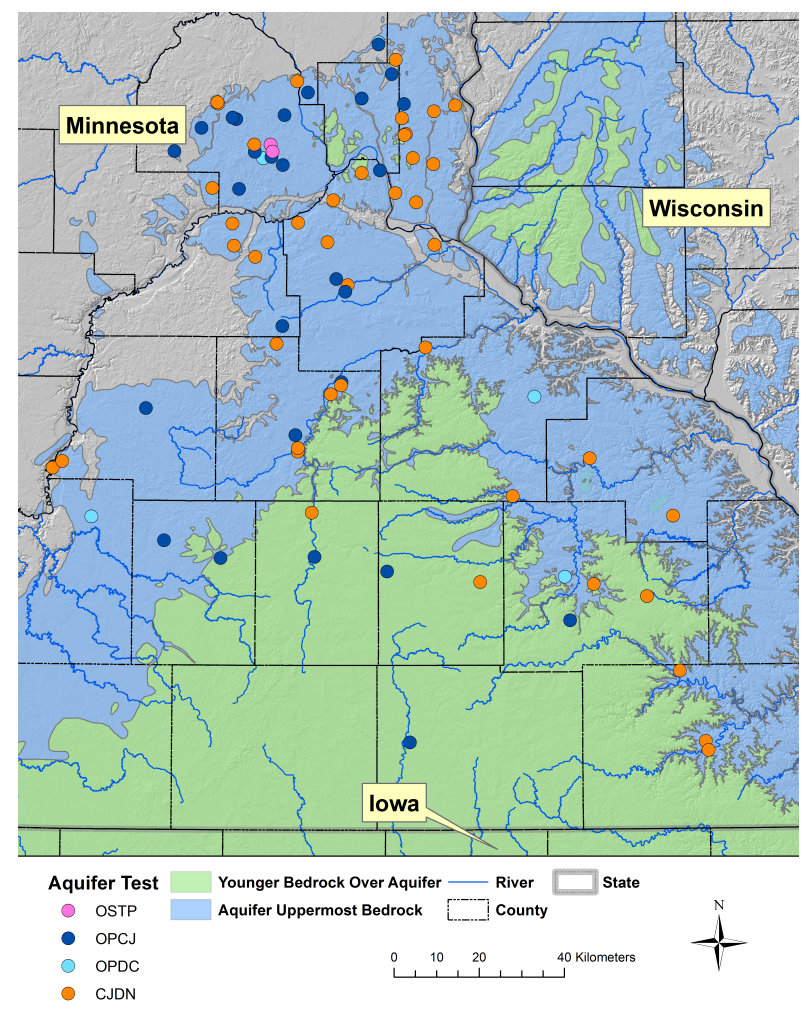

Figure 1. Aquifer Test Locations by Layer. 
the large aquifer extent; it is important to maximize the information gained from each test.

\section{Prairie du Chien-Jordan Aquifer Regional Hydrogeologic Setting}

Very nearly all of southeastern Minnesota is underlain by a sequence of Paleozoic bedrock formations that comprise the Prairie du Chien-Jordan Aquifer system (Figure 1; Table 1; Olcott 1992; Runkel et al. 2003; Figure 2).

\section{Prairie du Chien Aquifer}

The issue of fracture and solution enhanced (cavernous) flow in the Prairie du Chien Aquifer is well documented (Tipping et al., 2007). Karst landforms, sinkholes, caves, springs, and sinking streams are found where the Prairie du Chien Group is the uppermost bedrock unit. Not all void space and preferred zones of cavernous porosity were formed as a result of recent sub-aerial exposure; some were co-depositional. Therefore, zones of conduit flow typical of karst exist throughout the aquifer extent regardless of the type of geologic cover (Tipping et al. 2006). The subaerial exposure of the Prairie du Chien Group has reactivated old features and contributed to the development of new ones. The basal part Prairie du Chien Aquifer, the Oneota Formation, is massive dolostone with low porosity and few fractures. On a regional basis any head differences that are observed between the Prairie du Chien Group and Jordan Sandstone are attributed to the basal Oneota functioning as an aquitard.

\section{Coon Valley Member}

The contact of the Prairie du Chien Group with the older Jordan Sandstone is erosional (Tipping et al., 2006; Mossler, 2008). The Coon Valley Member of the Prairie du Chien Group is a dolostone-cemented silty sandstone that formed in topographic lows on the erosional surface on the top of the sandstone. The lateral extent of the Coon Valley Member is limited to the dendritic drainage pattern in which it formed, therefore the occurrence is both limited and quite unpredictable.

\section{Jordan Sandstone}

The Jordan Sandstone is a well-sorted medium-grained sandstone which appears to be fairly uniform over its extent. However, locally it contains lithological variations which lower the bulk hydraulic conductivity and bedding-plane fractures which increase the effective conductivity.

\section{Description of Aquifer Test Data}

Earlier compilations of his type of data have been limited to the Twin Cities Metropolitan area (Runkel et al. 1999) or selected communities (Runkel \& Mossler

\begin{tabular}{|c|c|c|c|}
\hline \multicolumn{2}{|c|}{ Aquifer Name } & $\begin{array}{c}\text { Primary Rock } \\
\text { Type }\end{array}$ & $\begin{array}{l}\text { Nominal } \\
\text { Thickness } \\
\text { (meter) }\end{array}$ \\
\hline \multicolumn{2}{|c|}{$\begin{array}{l}\text { Decorah-Platteville-Glen- } \\
\text { wood Aquitard } \\
\end{array}$} & $\begin{array}{c}\text { Shale and Do- } \\
\text { lostone }\end{array}$ & -- \\
\hline \multicolumn{2}{|c|}{ St. Peter Sandstone (OSTP) } & Sandstone & 30 \\
\hline \multicolumn{2}{|c|}{$\begin{array}{l}\text { Basal St. Peter Sandstone } \\
\text { (Twin Cities Basin) }\end{array}$} & $\begin{array}{c}\text { Siltstone and } \\
\text { Sandstone }\end{array}$ & 15 \\
\hline \multirow{4}{*}{$\begin{array}{l}\text { Prairie du } \\
\text { Chien Aqui- } \\
\text { fer } \\
(\text { OPDC) }\end{array}$} & Shakopee Fm. & Dolostone & 85 \\
\hline & $\begin{array}{l}\text { New Richmond } \\
\text { Sandstone }\end{array}$ & Sandstone & 10 \\
\hline & Oneota Fm. & Dolostone & 28 \\
\hline & $\begin{array}{l}\text { Coon Valley } \\
\text { Member }\end{array}$ & $\begin{array}{c}\text { Sandy Dolos- } \\
\text { tone }\end{array}$ & Variable \\
\hline \multicolumn{2}{|c|}{ Jordan Sandstone (CJDN) } & Sandstone & 30 \\
\hline \multicolumn{2}{|c|}{ St. Lawrence Aquitard } & $\begin{array}{l}\text { Dolostone } \\
\text { and Shale }\end{array}$ & -- \\
\hline
\end{tabular}

Table 1. Hydrogeologic Setting of the Prairie du Chien-Jordan Aquifer System - Confining Layers are Shaded.

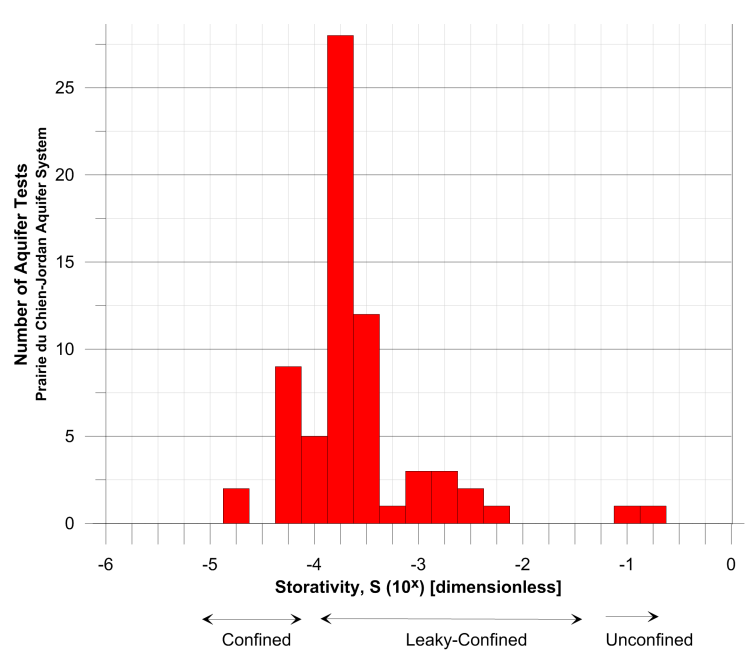

Figure 2. Histogram of Storativity Values from All Tests.

2001). The scope of this compilation is the whole extent of the aquifer system in Minnesota. MDH staff collected the test data for approximately half of the tests; the source data of those tests are on file. The raw data of tests conducted by others is also obtained whenever possible. Source data from all but eight tests are available. This is critically important because access to the source data has permitted well-documented tests to be reinterpreted without having to repeat the test. 
The numbers of tests by aquifer layer are shown in Table 2. The geographic distribution of tests is shown in Figure 1. The greatest numbers of tests have been performed in the Twin Cities metropolitan area and the Bluffland area of southeastern Minnesota where the Prairie du Chien Aquifer is the uppermost bedrock. Comparatively few tests have been performed in the area with a significant thickness of younger bedrock cover.

Descriptive statistics of aquifer properties are shown in Figures 2 and 3. Most tests were conducted in confined to leaky-confined hydraulic conditions. Three tests were performed in a hydraulically unconfined setting. The box and whisker plots, Figure 3, are standard Tukey quartiles; showing interquartile ranges (IQR), the median value and outliers as greater than or less than $1.5 *$ IQR . Figure 4 shows a cross-plot of leakage factor vs. Storativity. There is an ill-defined unit-slope for these data with slight differences in the populations by aquifer layer.

A detailed account of the analysis methodology for each test is beyond the scope of this paper as most tests were analyzed with multiple techniques. The intent here is to outline the general approach to analysis that was developed for these data, demonstrate that the opposing assumptions of standard transient and steady-state methods are useful to constrain parameter estimates, and how an assessment of well efficiency is required to reduce uncertainty of aquifer properties.

\section{Well Hydraulics}

The first issue considered in the analysis process is the relative efficiency of the pumped well. The drawdown in the pumping well as compared to that in the aquifer defines the hydraulic efficiency of the well. (Jacob 1947) Two prominent naturally occurring features of the aquifer system, sub-horizontal bedding-plane fractures and solution enhanced conduits, cause wells to produce water very efficiently relative to wells that do not intersect such features. In addition, well development practices affect the hydraulic performance of the pumping well.
As scientists, we have a well-founded bias that efficiency cannot exceed $100 \%$. This is not true for Jordan Sandstone wells that have been developed by the "blast and bail" technique. Dynamite is placed in the well and detonated to break up the rock. Broken rock is then bailed from the well to create a large cavern in the formation. In some cases hundreds of cubic meters of sand are removed from the well. The actual diameter of this cavern is never known exactly but it is certainly much larger than the diameter of the original borehole from the driller's record.

The combination of natural features and an enlarged borehole causes an increase in specific capacity of the well; a smaller drawdown in the well for the work exerted to remove a given volume of water. Thereby, from the perspective of the aquifer properties - the well appears to be more than $100 \%$ efficient. Conversely, a lower transmissivity zone may be encountered by the pumping well, such as the Coon Valley Member. This would result in an under-efficient pumping well because of the local difference in bulk hydraulic conductivity. Once the efficiency of the pumping well is accounted for in the analysis certainty in the local aquifer properties is increased.

No tests, to-date, show the distinctive hydraulic characteristics of linear $(\sqrt{ }(t))$ vs. radial $(\log [t])$ flow in this aquifer system. (Gringarten \& Witherspoon, 1971) This is the case even in instances where boreholes show nearly simultaneous response to pumping at different wells. The assumption of porous media flow equivalency in the Prairie du Chien Aquifer is a good starting point for interpretation of test data. However, more subtle effects of radial conduit flow have become evident with the accumulation of test data.

Groundwater flow theory states that the impact of a high permeability fracture intersecting the wellbore will show a characteristic $1 / 2$ unit-slope on a $\log$-s vs. $\log$-t plot. Similarly, because of increased wellbore storage, a cavern developed in the formation should cause a unit-slope

\begin{tabular}{|lcccc|}
\hline Aquifer Name & Prairie du Chien-Jordan & Prairie du Chien & Jordan & Sub Totals \\
Single well tests & 4 & 1 & 5 & 10 \\
Tests with observation wells & 26 & 5 & 43 & 74 \\
\hline Total number of tests & 30 & 6 & 48 & 84 \\
\hline
\end{tabular}

Table 2. Numbers of tests by layer. 

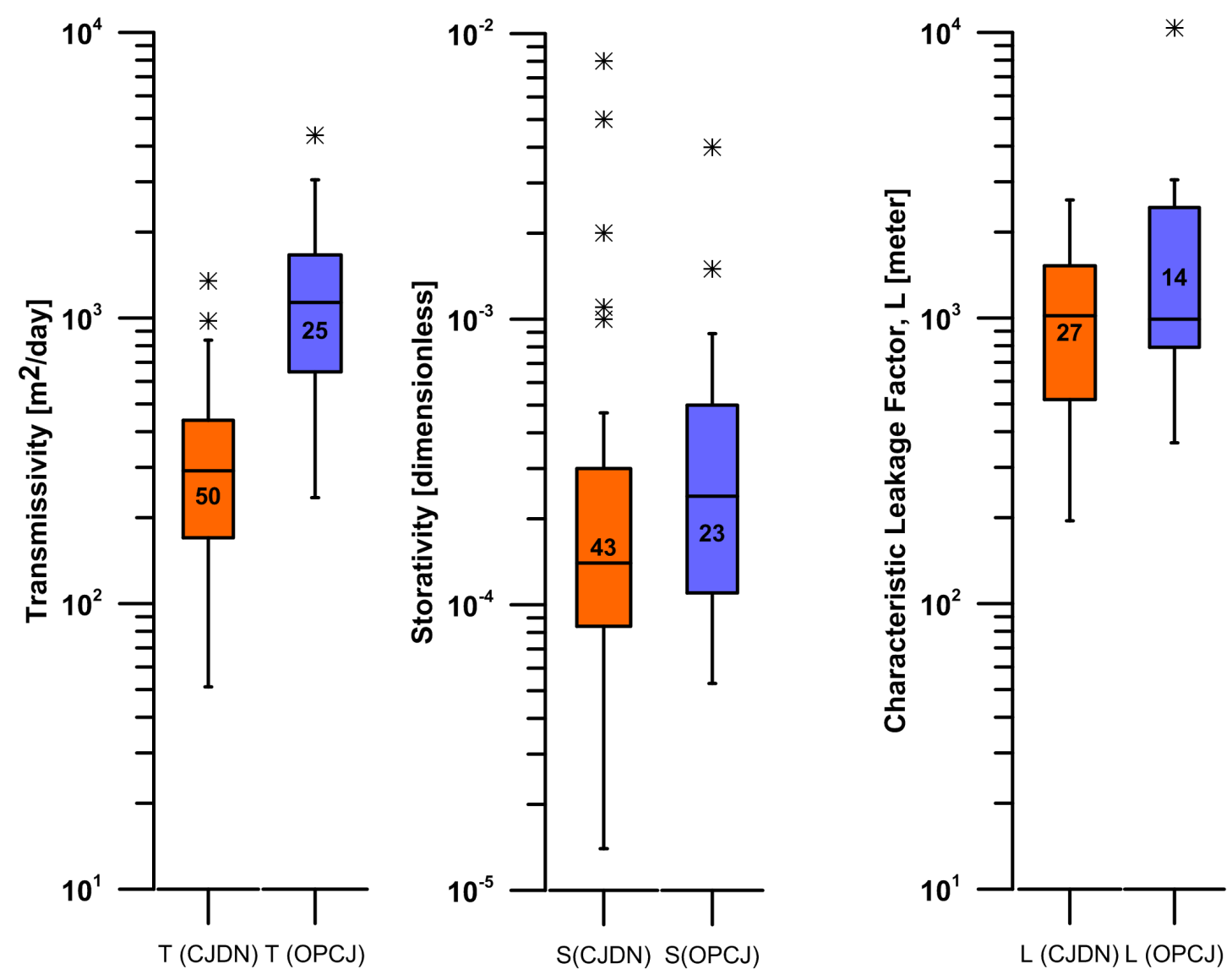

Aquifer Layer

Prairie du Chien-Jordan (OPCJ)

Jordan Sandstone (CJDN)

Figure 3. Descriptive Statistics for Layers with 30 or More Tests.

on the same plot. (Gringarten, 2008) In the existing dataset, the only early-time deviations from the Theis curve have been of the unit slope, characteristic of well-bore storage. This indicates that the hydraulic effect of both the sub-horizontal bedding-plane fractures and zones of cavernous secondary porosity is to create an enlarged borehole.

The dataset of aquifer tests is used to support the development of regional groundwater flow models that are concerned with protecting drinking water quality. As the aquifer system is, by and large, hydraulically confined (Figure 2), the source of water to the system is vertical flow (leakage) through adjacent confining units. Therefore, characterization of leakage is a focus of these analyses.

\section{Analysis Techniques}

The simple inverse models used to analyze aquifer tests are of two basic types, transient and steady-state. The transient conceptual model (Theis, 1935; Cooper \& Jacob 1946) assumes that all water flows to the well from infinity and the aquifer is perfectly confined (no leakage). On this basis, all analyses that exclusively use the Theis conceptual model have limited utility for model development in layered systems.

The steady-state conceptual model (de Glee, 1930; Hantush \& Jacob, 1955) assumes that there is no change in storage in the aquifer and that the source of water is from leakage through adjacent aquitard(s). Familiar modifications to the transient conceptual model to include the effects of leakage were introduced by Hantush (1960), Walton (1960), and Neuman and Witherspoon (1972). 


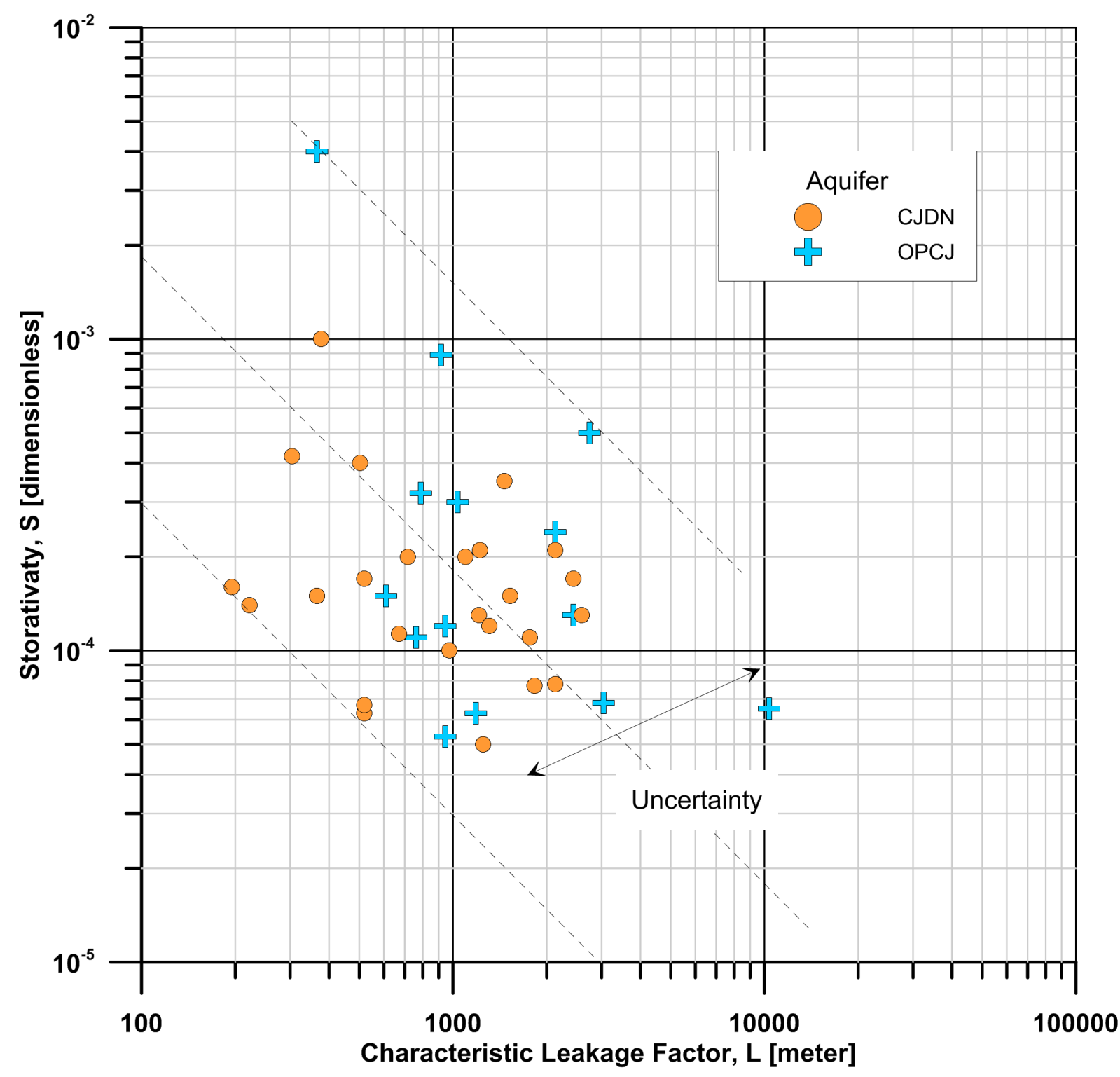

Figure 4. Leakage Factor vs. Storativity by Aquifer.

Blended opposing conceptual models have been used for many years, however few practitioners think to use the steady-state analysis techniques unless leakage is clearly indicated during a test.

Recharge of some sort must be considered to be present in all tests. All saturated confined-layered systems are replenished by leakage; leakage must be quantified for the aquifer properties to be adequately defined. This approach is not new. For instance, aquifer tests were used to examine the leaky characteristics of 'tight' formations for natural gas storage (Witherspoon et al., 1967). However, the reservoir engineering perspective is not often applied to groundwater problems.

\section{Linked Parameters: T, S, and L}

In the mathematics of the Theis well function, transmissivity (T) and storativity (S) are linked parameters. Basic groundwater flow theory associates ranges of values of storativity with unconfined, leaky-confined, and confined flow regimes. Steady-state flow, as applied to leaky-confined and confined settings, also links transmissivity to the characteristic leakage factor (L). For leaky settings, L, is small - on the order of hundreds of meters; conversely for settings with little leakage, L is large - on the order of thousands of meters.

The premise of this analysis procedure is that all three parameters are linked. Therefore for a given trans- 
missivity, both the storativity and leakage must 'make sense' with respect to the hydrogeologic setting. Quantitatively, storativity and characteristic leakage factor are inversely related. A small storativity should be associated with very small volume of leakage, a large leakage factor. Conversely, large storativity should be associated with a large volume of leakage, a small leakage factor. Given this linkage between the parameters T, S, and L, an approach has been developed to deal with the effects of flow through cavernous porosity, bedding-plane fractures, and an enlarged borehole as shown by the following examples.

\section{Examples of Anomalous Hydraulic Response}

When observation wells were used, the most effective way to detect and then account for the anomalous patterns is to plot all data from a test on one graph with the Theis distance-drawdown plot, log-s vs. log- $\mathrm{t} / \mathrm{r}^{2}$.

\section{Under-Efficient Pumping Well}

A test was performed on a high-capacity well for an ethanol plant to satisfy state permitting requirements (Champion 2008; Blum 2013). In this example, the wells were completed open-hole over both the Prairie du Chien and Jordan portions of the aquifer system. The hydrogeologic setting was deep confined with a significant thick- ness of younger bedrock and clay-rich till cover. Therefore, the setting should produce a small storativity, in the range of $10^{-5}$. Two wells were monitored; pumping and an observation well, located 479 meters (1570 feet) apart. Figure 5 shows the effect of an under-efficient pumping well.

Drawdowns in the pumping well are greater than what would be predicted by the Theis curve match to the observation well. The storativity calculated from this data is large for the setting, at $10^{-4}$.

Figure 6 shows the data from observation well from this test in more detail with a Theis analysis. It can be seen that the effect of start of pumping/recovery traveled 480 meters in about 30 seconds. This rate of propagation, about 16 meters per second, clearly indicates fracture/ conduit flow. The trend of the early-time data $(<10 \mathrm{~min}-$ utes) approximates the unit-slope that is characteristic of wellbore storage.

The unit-slope departure of early-time data from the Theis curve in nearby observation wells is frequently observed in this aquifer system. For tests with several observation wells the anomalous response is damped and becomes more 'Theisian' in more distant wells. Note

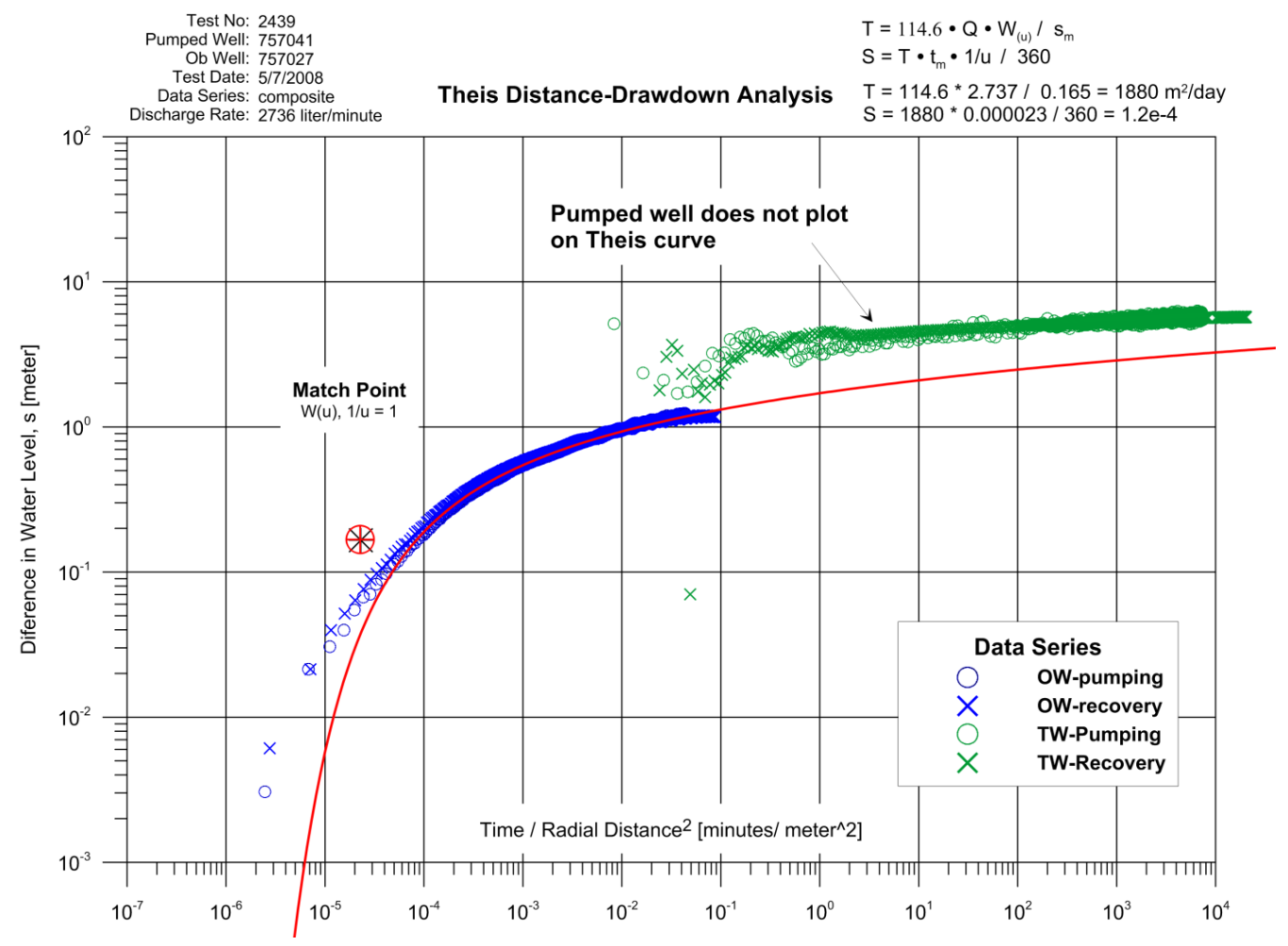

Figure 5. Example of an Under-Efficient Well. 


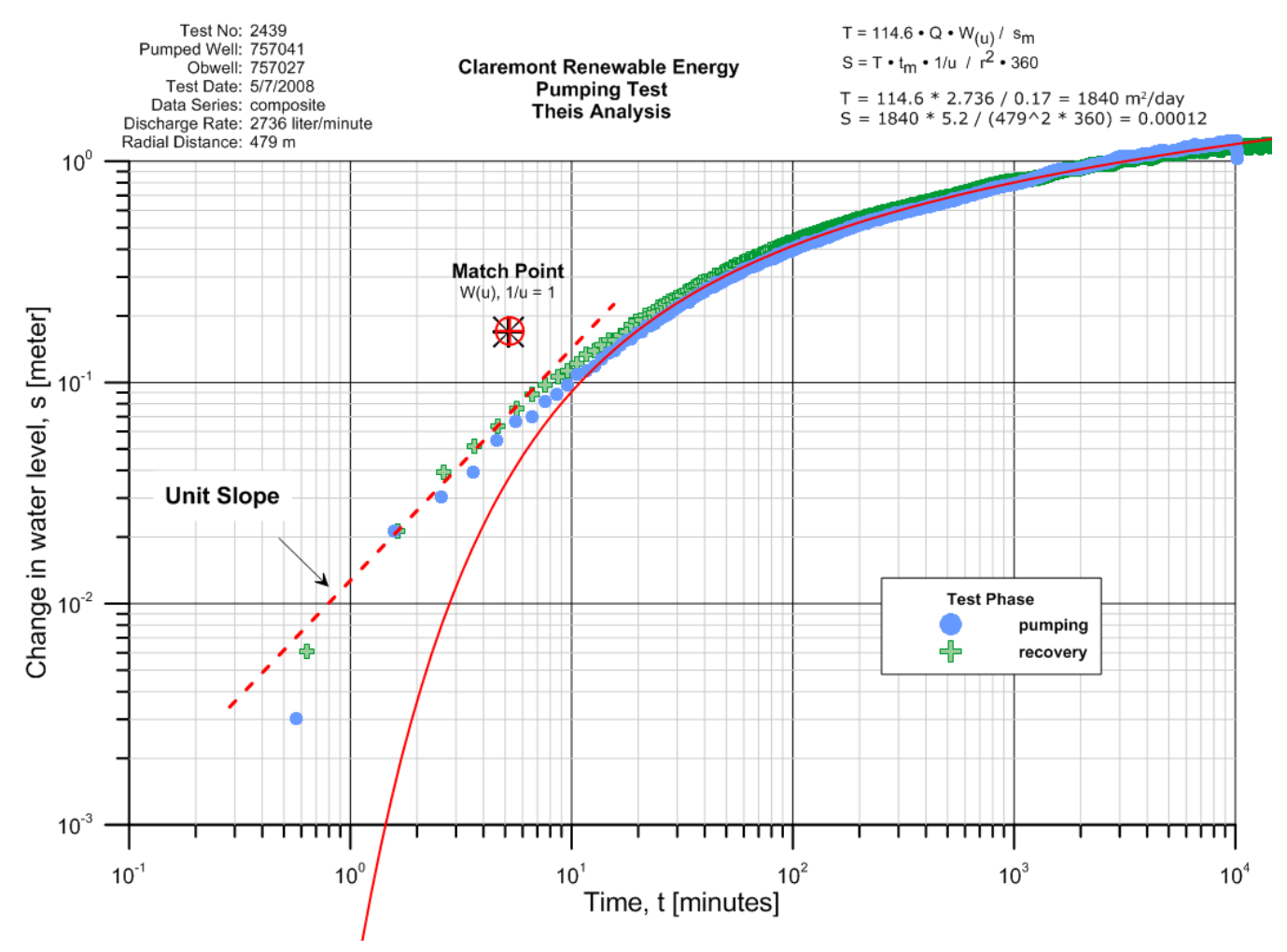

Figure 6. Unit-slope of Early-Time Data.

that the half -unit slope trend that indicates a high permeability fracture may only be observed in very early time ( $<30$ seconds) which is rarely captured in sufficient detail.

Interestingly, the unit-slope trend is not often observed in the pumping well itself, such as the case with this testeven those wells equipped with transducers which rapidly collect data in early-time. It appears that transient mechanical and other well hydraulic issues obscure the unit-slope response in the pumping well. For this test there were an insufficient number of observation wells to be able to reliably estimate the characteristic leakage factor. The hydrogeologic setting would cause the leakage factor to be large, probably greater than 6,000 meters ( 20,000 feet).

\section{Over-Efficient Pumping Well}

A recently completed production test of Rochester 41 provides a good example of the effect of an over-efficient well. (Blum, 2014)

Well 41 is located on the east side of the Rochester basin in an area where the uppermost bedrock is the Prairie du Chien Group with scattered patchy remnants of the
St. Peter Sandstone. Well 41 was completed in the Jordan Sandstone and had been developed by the blast and bail method. Approximately $115 \mathrm{~m}^{3}$ (150 cubic yards) of sand were removed from the well. Based on the volume of sand removed and the length of open hole, the enhanced borehole radius is at least $1.1 \mathrm{~m}$ (3.6 feet)

The production test was conducted at a constant rate of 4580 liter/minute (1210 gallons per minute) for 24-hours. The driller measured water levels manually at the pumped well. Observation wells were four other nearby Rochester Public Utilities (RPU) water supply wells which were monitored by the utility's data acquisition and control system on a five-minute interval (Figure7).

Other known interfering wells were the production wells in the RPU system. The manual data collection at the pumped well precluded any early-time data but those data collected appear to be of high quality. Problems in data collection/reporting were that some transducers in the wells report to nearest 1 to 2 feet rather than the normal 0.01 foot resolution. This is a common problem when these data are used for scientific purposes rather than the design purpose. 


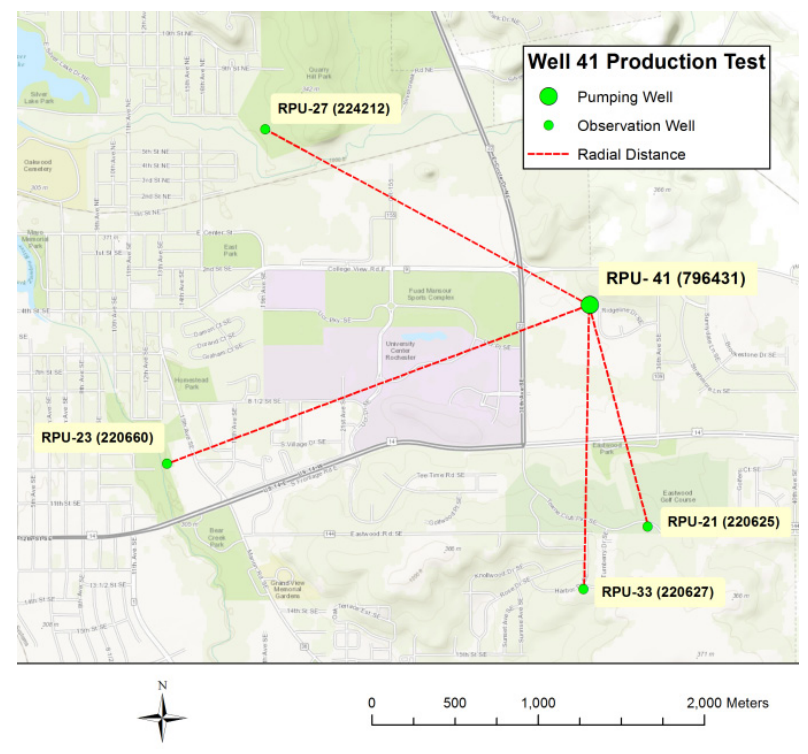

Figure 7. Wells Monitored During W4 1 Production Test.
For this reason, plots of all water level readings, collected on a five-minute interval, appear 'noisy.' The analysis plots use water level readings from the observation wells on a half-hour interval for a more clear view of hydraulic response.

Well interference was a significant factor as three of the four observation wells were affected by cycling of their pumps at some time during the test. In particular, data from well 27 (224212) was not usable as this well was in recovery over the time span of the test and no discernable drawdown caused by Well 41 was found. Wells 21 and 23 cycled after 23-hours into the test and therefore only the pumping-phase data were usable.

Limited recovery data were collected from the pumped well only. This test setup was not ideal; however, serviceable data were obtained for analysis. The Theis $t / r^{2}$ analysis of these data is shown on Figure 8.

There is significant scatter in the drawdowns at the observation wells. The response of Well 21 may be influenced by multi-aquifer well construction. The response of Well 23 may be influenced by proximity to surface

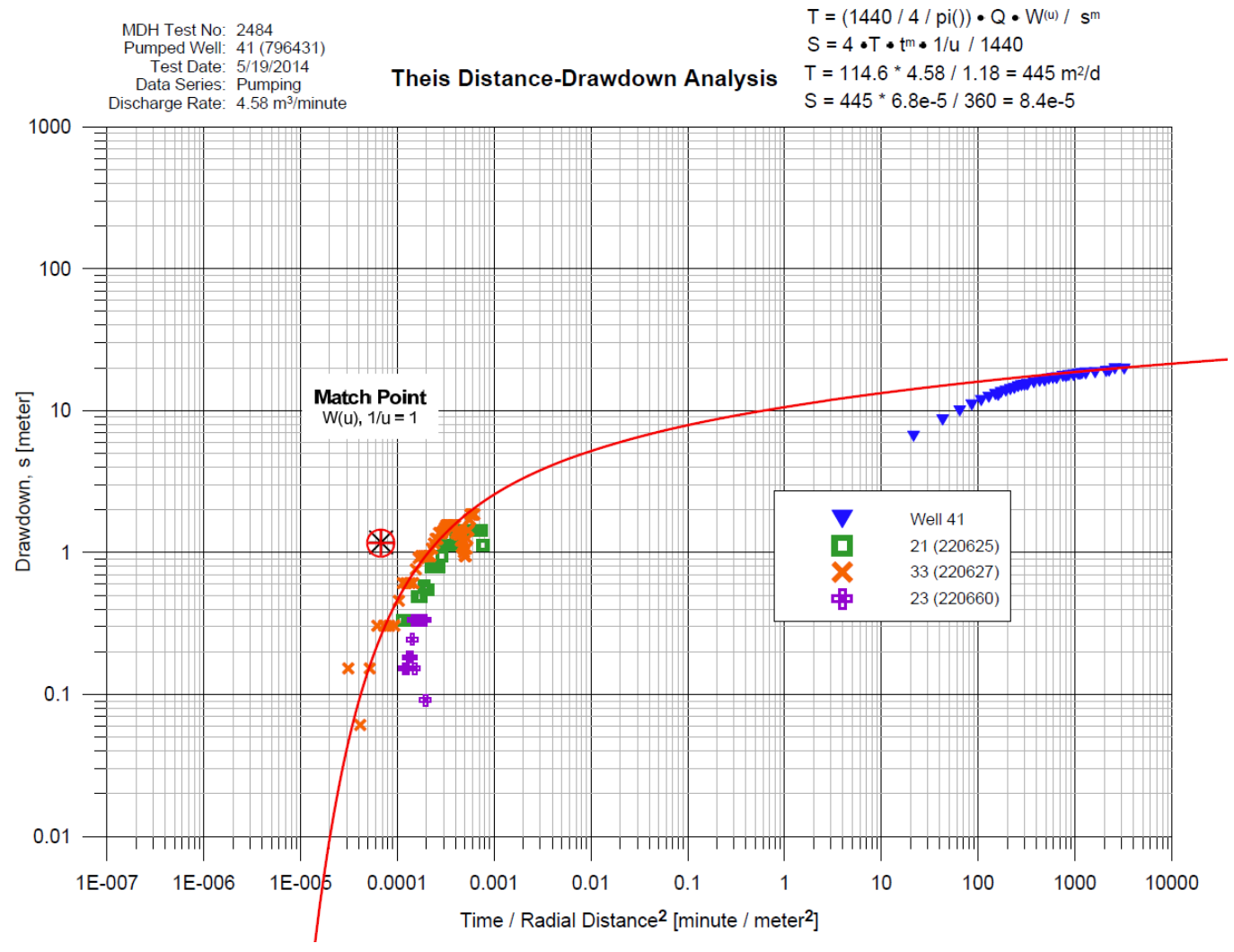

Figure 8. Initial Analysis, Theis t/r2 plot. 
water. Though, it is common for drawdown at a distant observation well to be smaller than expected, with respect to the Theis curve. Therefore, the analysis weights the response of the closest Jordan Sandstone well, Well 33 , most heavily.

A strong indication that anomalous hydraulic responses are present in the data is that there is significant variability in aquifer properties between wells and analysis techniques (Table 3).

The effective radius of the pumped well may be estimated by different means depending on the quality of the dataset. If a sufficient number of observation wells at a range of radial distances were used a semi-log regression on the distance-drawdown data using the observation wells only provides an initial value of $r$. Otherwise,

\begin{tabular}{|c|c|c|l|}
\hline Figure & $\begin{array}{c}\text { Transmissivity } \\
\mathrm{m}^{2} / \mathrm{d}\end{array}$ & Storativity & $\begin{array}{l}\text { Well - } \\
\text { Analysis } \\
\text { Method }\end{array}$ \\
\hline 8 & 445 & $8.4 \mathrm{e}-5$ & Theis $\mathrm{t} / \mathrm{r}^{2}$ \\
\hline 9 & 180 & $5.3 \mathrm{e}-1$ & W41-Agarwal \\
\hline 10 & 350 & $8.7 \mathrm{e}-5$ & W33-Theis \\
\hline
\end{tabular}

trial and error adjustment of the radius of the pumped well to match the Theis curve is the only recourse. The resulting estimate of effective radius must then be tested with other analysis plots to verify consistency with the hydrogeologic setting.

In this case, the distances to the observation wells are not well-distributed; all observation wells are greater than $1000 \mathrm{~m}$ from the pumped well. A semi-log distancedrawdown regression is not informative. Trial and error adjustment of the effective radius of the pumped well resulted in an optimal value of r, $7.6 \mathrm{~m}$ (25 feet) and a value of transmissivity of $287 \mathrm{~m}^{2} / \mathrm{d}$ (Table 4). With the revised wellbore radius visual matches to the typecurves are consistent between analysis techniques (Figures 11 and 12).

Without the revised wellbore radius of the pumping well, there is significant uncertainty in the match to the steadystate well curve; particularly with respect to the horizontal match, L (Figure 12). In addition, if a borehole radius

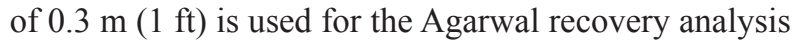
(Agarwal, 1980), this results in a non-credible storativity of 0.5 (Figure 9). Whereas, using a radius of $7.6 \mathrm{~m}$ in the calculation, the resulting storativity is large, $8.2 \mathrm{e}-4$, but is physically possible.

Table 3. Initial Assessment of Aquifer Properties.

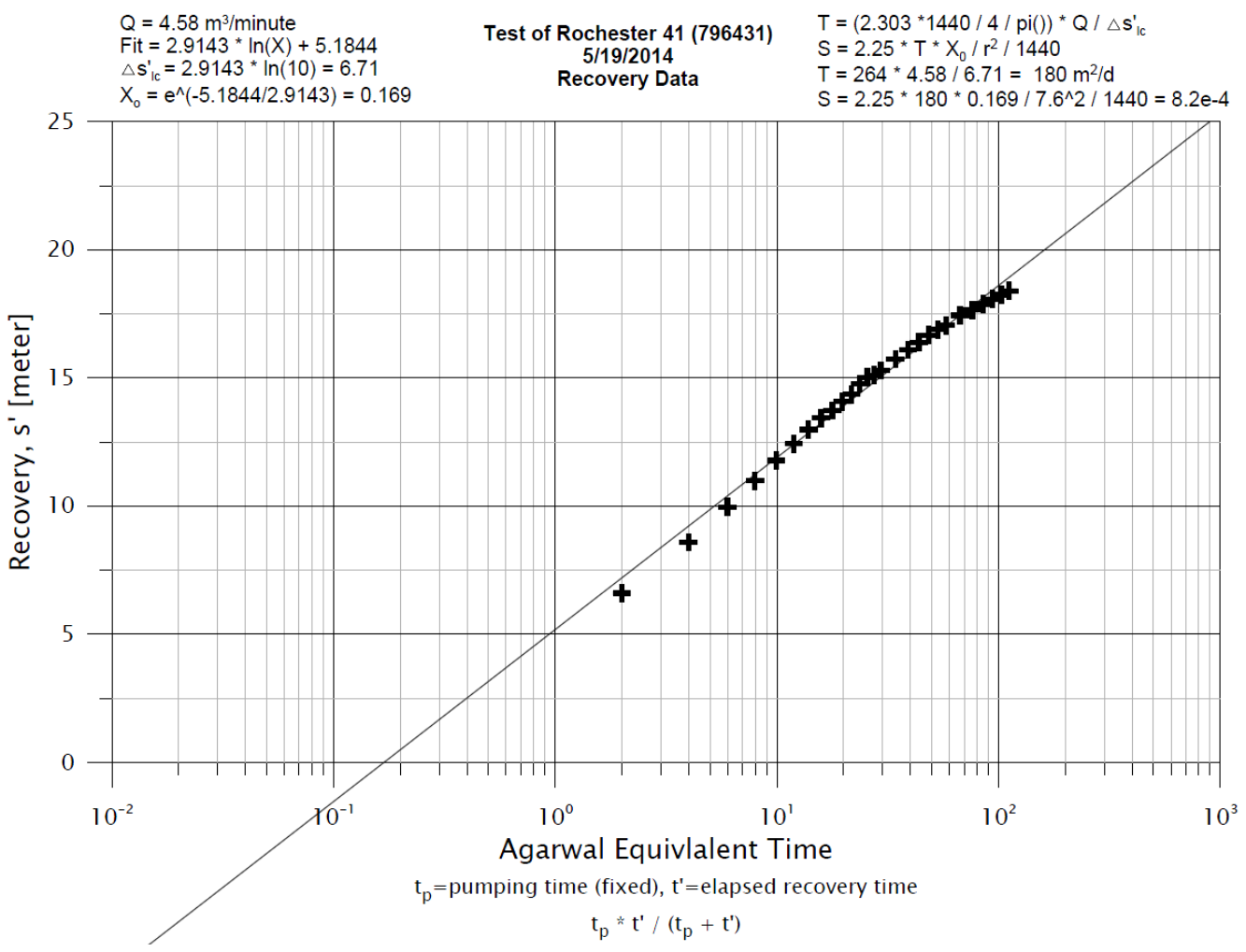

Figure 9. Agarwal Recovery Analysis. 


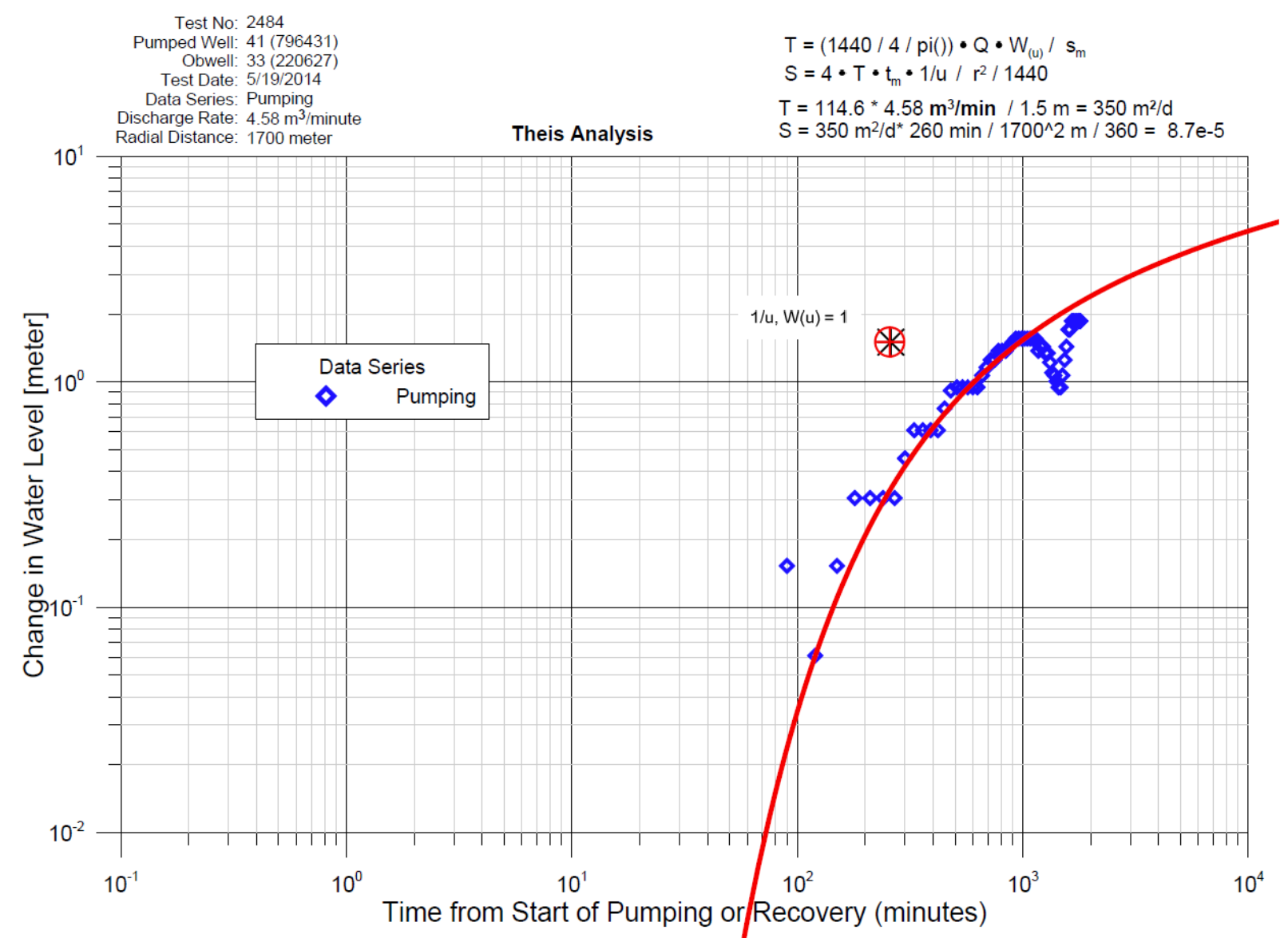

Figure 10. Theis Analysis, W33.

\begin{tabular}{|c|c|c|c|c|}
\hline Figure & $\begin{array}{c}\text { Transmissivity } \\
{\left[\mathrm{m}^{2} / \mathrm{d}\right]}\end{array}$ & Storativity & $\begin{array}{c}\text { Characteristic } \\
\text { Leakage Factor } \\
{[\mathrm{m}]}\end{array}$ & Analysis Method \\
\hline 9 & 180 & $8.2 \mathrm{E}-04$ & -- & Agarwal \\
\hline 11 & 287 & $8.0 \mathrm{E}-05$ & -- & Theis $\mathrm{t} / \mathrm{r}^{2}$ \\
\hline 12 & 287 & -- & 1830 & de Glee \\
\hline 13 & 288 & $9.9 \mathrm{E}-05$ & 2380 & Hantush-Jacob/Cooper-Jacob \\
\hline
\end{tabular}

Table 4. Aquifer Properties after Accounting for Large Effective Borehole Radius.

The estimate of L from the Hantush-Jacob analysis, Figure 13 , is not as reliable as that from the de Glee analysis, Figure 12. This results from the sensitivity of this technique to an error introduced by using wells located at distances greater than $0.2 \mathrm{~L}$. In this case, no wells within $0.2 \mathrm{~L}$ were monitored and the Hantush-Jacob analysis is poorly constrained.

\section{Conclusion}

Application of this method depends on the number of observation wells monitored during a test. Given a suf- ficient number of observation wells, distance-drawdown analysis techniques, $\left[\log (\mathrm{s})\right.$ vs. $\log \left(\mathrm{t} / \mathrm{r}^{2}\right)$ and $\log (\mathrm{s}) \mathrm{vs}$. $\log (\mathrm{r})]$, produce the most consistent results. Uncertainty in transmissivity values is significantly reduced by accounting for well efficiency, avoiding data influenced by wellbore storage, and solving for consistent values of linked parameters; storativity and leakage factor.

As described, this procedure accounts for peculiarities of the hydraulic response in wells in this aquifer system to arrive at a consistent transmissivity based on the dif- 


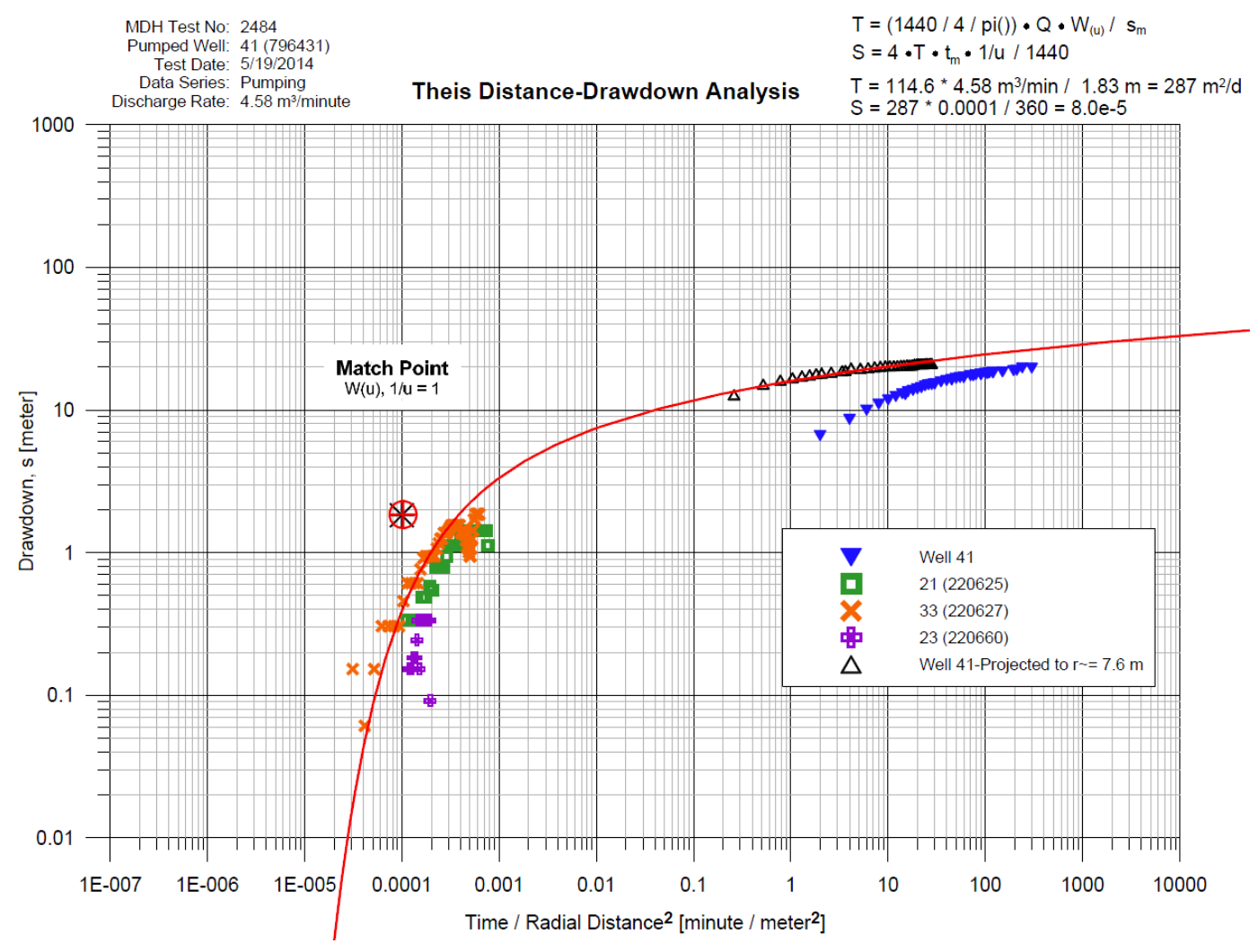

Figure 11. Theis $t / r 2$, Projected to $r=7.6 \mathrm{~m}$.

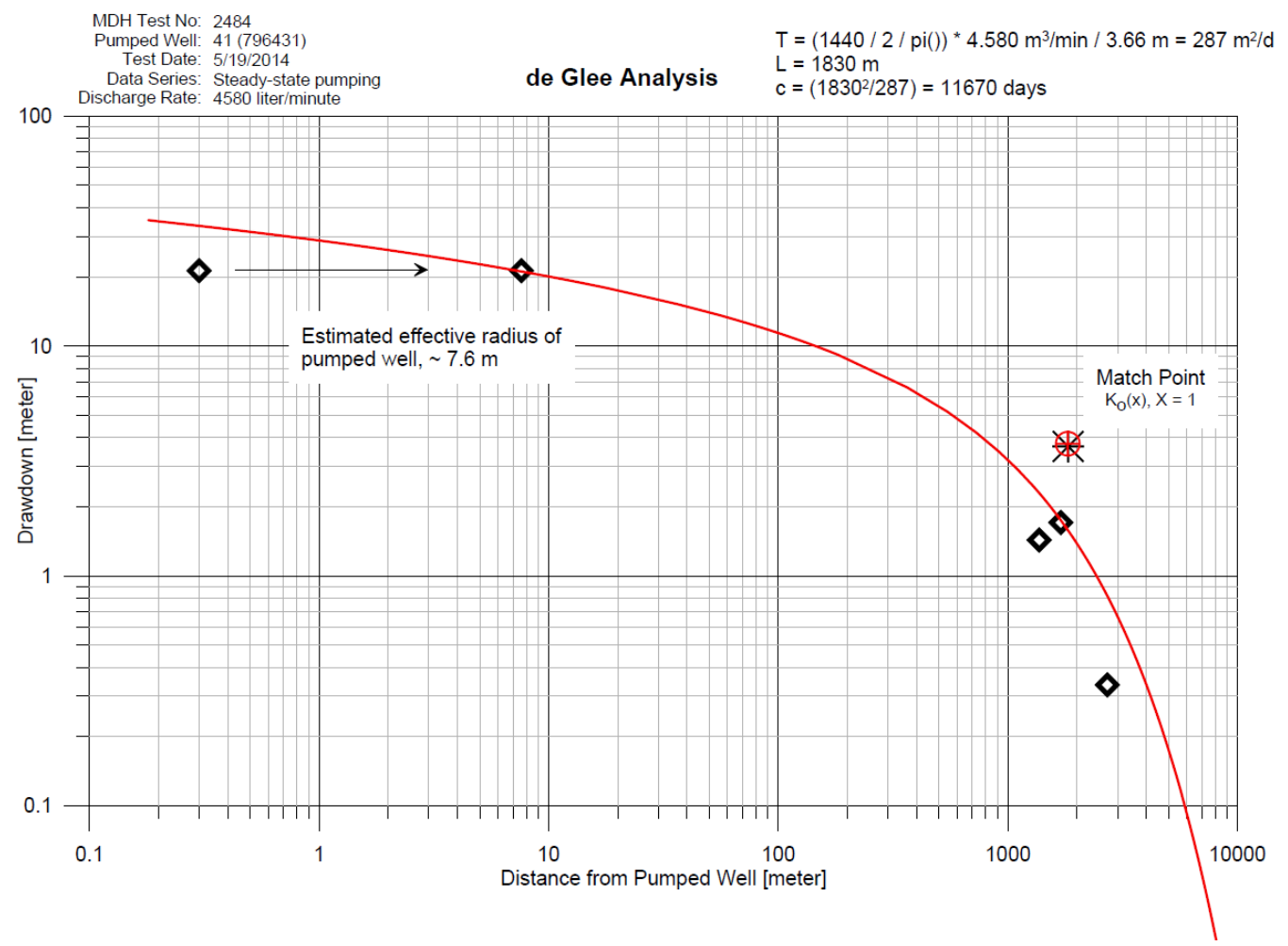

Figure 12. Log-log Distance-Drawdown. 


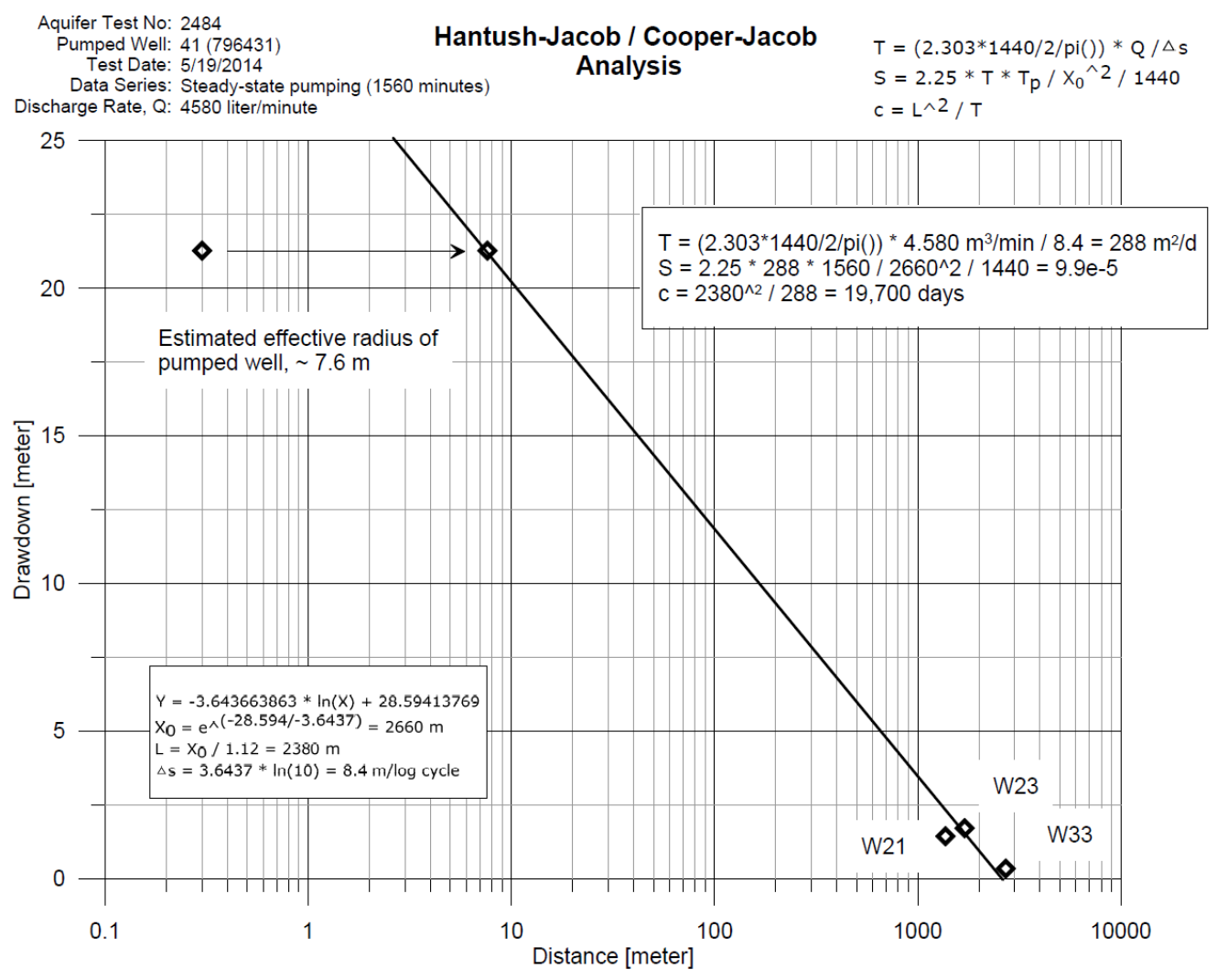

Figure 13. Semi-log Distance-Drawdown.

ferent assumptions of the source of water to the well. If the large effective borehole radius is not recognized and accounted for, the apparent variability of all hydraulic properties; transmissivity, storativity and leakage factor increase. And more significantly, without the enlarged borehole radius, the correlation between the linked parameters is weakened.

Uncertainty in storativity is low because it is based on a time of propagation of a pressure change in the aquifer that is relatively insensitive to differences in transmissivity. The least certain parameter is the characteristic leakage factor. This approach to aquifer test analysis has significantly reduced the uncertainty in local aquifer properties and enhanced the quality of the overall dataset.

\section{References}

Agarwal RG. 1980. A new method to account for producing time effects when drawdown type curves are used to analyze pressure buildup and other test data. In Proceedings of SPE. 55th Sociey of Petroleum Engineers Annual Technical Conference and Exhibition. Dallas, Texas.

Blum JL. 2013. Analysis of the Claremont Renewable Energy (757041) Pumping Test, 5/7/2008, Confined Prairie du Chien-Jordan Aquifer. Claremont, Minnesota: Minnesota Dept. of Health.

Blum JL. 2014. Analysis of the W41 (796431) Production Test, May 19, 2014 Jordan Sandstone Aquifer. Rochester, Minnesota: Minnesota Dept. of Health.

Champion G. 2008. Aquifer Test Report - Claremont, Minnesota, Ethanol Production Facility - for Claremont Renewable Energy, LLC, Natural Resource Group, LLC (NRG).

Cooper HH, Jacob CE. 1946. A Generalized Graphical Method for Evaluating Formation Constants and Summarizing Well-field History. Trans. American Geophysical Union, 27, p. 526 - 534.

de Glee G. 1930. Over grondwaterstroomingen bij wateronttrekking door middle van putten. Ph.D. Delft, Netherlands: Delft Technische Hogeschool. 
Available at: http://repository.tudelft.nl/assets/ uuid:c3e13209-4626-41b9-9038-c223d61e35c4/ deGlee1930.pdf.

Gringarten AC. 2008. From Straight Lines to Deconvolution: The Evolution of the State of the Art in Well Test Analysis. SPE Reservoir Evaluation \& Engineering, 11 (1). [Accessed April 16, 2013] Available at: http://www.spe.org/ ejournals/jsp/journalapp.jsp?pageType=Preview\&j id=EREE\&mid=SPE-102079-PA\&pdfChronicleId $=09014762801630 \mathrm{bc}$.

Gringarten AC, Witherspoon PA. 1971. A method of analyzing pump test data from fractured aquifers. Proceedings of the Symposium on Rock Mechanics, T3-B, p. 1-8.

Hantush MS. 1960. Modification of the Theory of Leaky Aquifers. Journal of Geophysical Research 65: 3713-3725.

Hantush MS, Jacob CE. 1955. Steady Three-dimensional Flow to a Well in a Two-layered Aquifer. Trans. American Geophysical Union 36: 286-292.

Jacob CE. 1947. Drawdown Test to Determine the Effective Radius of Artesian Wells. Transactions of the American Society of Civil Engineers 112: $1047-1170$.

Mossler JH. 2008. Paleozoic Stratigraphic Nomenclature for Minnesota, Minnesota Geological Survey, University of Minnesota. Available at: http://purl. umn.edu/58940.

Neuman SP, Witherspoon PA. 1972. Field determination of the hydraulic properties of leaky multiple aquifer systems. Water Resources Research, 8 (5): 1284.

Olcott PG. 1992. Ground Water Atlas of the United States: Segment 9, Iowa, Michigan, Minnesota, Wisconsin. Hydrologic Atlas, p.1 atlas (31 p.) :col. ill., col. maps ;59 x $46 \mathrm{~cm}$.

Runkel AC. et al., 2003. RI-61 Hydrogeology of the Paleozoic bedrock in southeastern Minnesota, Minnesota Geological Survey, University of Minnesota. Available at: http://purl.umn. edu/58813.

Runkel AC, Kanivetsky R, Tipping RG. 1999. Hydraulic and Hydrostratigraphic Characteristics of the Prairie $\mathrm{Du}$ Chien-Jordan Aquifer System in the TwinCities Metropolitan Area, Minnesota., Minnesota Geological Survey, University of Minnesota.

Runkel AC, Mossler JH. 2001. Hydrostratigraphic and hydraulic characterization of Paleozoic bedrock at nine southeastern Minnesota communities: research in support of wellhead protection, Minnesota Geological Survey, University of Minnesota. Available at: http://conservancy.umn. edu/handle/108833.
Teutsch G, Sauter M. 1991. Groundwater modelling in karst terrains: Scale effects, data acquisition and field validation. In Proceedings of the Third Conference on Hydrogeology, Ecology, Monitoring, and Management of Groundwater in Karst, ed. J. Quinlan, 17-34. Nashville, Tennessee.

Theis CV. 1935. The Relation Between the Lowering of the Piezometric Surface and the Rate and Duration of Discharge of a Well Using Ground-Water Storage. Trans. American Geophysical Union 16: 519-524.

Tipping RG, et al. 2007. Bedrock geology, topography, and karst feature inventory of Steele, Dodge, Olmsted and Winona Counties, Steele, Dodge, Olmsted and Winona Counties, Minnesota: Minnesota Geological Survey. Available at: http:// purl.umn.edu/123367.

Tipping RG, et al. 2006. Evidence for hydraulic heterogeneity and anisotropy in the mostly carbonate Prairie du Chien Group, southeastern Minnesota, USA. Sedimentary Geology, 184 (3-4): 305-330.

Walton WC. 1960. Leaky artesian aquifer conditions in Illinois, Springfield: Illinois State Water Survey. Available at: http://www.isws.uiuc.edu/pubdoc/RI/ ISWSRI-39.pdf.

Witherspoon PA, et al. 1967. Interpretation of aquifer gas storage conditions from water pumping tests, New York: American Gas Association. Available at: http://lccn.loc.gov/67063074. 
